\title{
OPTIMASI SUMBER DAYA ALAM MELALUI TEKNOLOGI TEPAT GUNA DALAM BIDANG BISNIS UNTUK MASYARAKAT DUSUN PATEH KECAMATAN SELAT KABUPATEN KARANGASEM
}

\author{
I.G.K. Sukadana ${ }^{1}$, I.G.N.P. Tenaya ${ }^{2}$, dan I.M. Astika ${ }^{3}$
}

\begin{abstract}
ABSTRAK
Dusun Pateh dan dusun Wates Kaje terletak di daerah lereng bukit pintu. 180 kepala keluarga sebagian besar hidup dari pertanian. Belum tersedianya air bersih dikedua dusun tersebut, rendahnya kesadaran masyarakat pada kesehatan dan kebersihan lingkungan, produktivitas masyarakat rendah, air terjun Jaga Satru belum tertata dan terpublikasikan sebagai objek wisata, tingkat penjualan produk olahan salak bali rendah.Target program kkn-ppm: Meningkatnya kesehatan masyarakat dengan tercukupinya air bersih, kebersihan lingkungan serta penyuluhan pola hidup bersih dan sehat. Meningkatkan pengetahuan masyarakat dengan ketersediaan buku bacaan dan tertatanya fasilitas ruang baca. Meningkatnya produktivitas masyarakat. Efisiensi biaya melalui pendampingan dan pengenalan teknologi pompa hydram. Metode pelaksanaan: penyuluhan, pendampingan, gotong royong, penerapan teknologi tepat guna, dan metode percontohan. Hasil Kegiatan KKN-PPM; Sistem air bersih di dusun Pateh dengan metode pompa hydram sudah terealisasi, hasil evaluasi menunjukan jumlah air yang dipompakam sampai ke lokasi sebesar 43.200 liter /hari. Kebutuhan air setiap orang setiap hari 80 liter/hari maka cukup untuk 540 orang atau $108 \mathrm{KK}$. Sistem air bersih metode gravitasi di dusun Wates Kaja sudah terlaksana dengan baik dan distribusi air lebih merata. Kegiatan PHBS sudah terlaksana dengan capaian 50 siswa SD 6 Duda Timur. Pelayanan kesehatan ternak capaiannya 30 ternak sapi. Kegiatan penghijauan 100 pohon kelapa daksina telah terlaksana dilingkungan air terjun. Kegiatan publikasi wisata air terjun Jaga Satru dengan metode balihoo sudah terlaksana dan kunjungan wisatawa asing mengalami peningkatan sebesar $100 \%$. Kegiatan kebersiha lingkungan dengan menempatkan 3 buah keranjang sampah untuk mengumpulkan sampah anorganik. Pembuatan Master Plant wisata air terjun jaga satru $100 \%$ terlaksana, dan blog desa duda sudah terpublikasi.
\end{abstract}

Kata Kunci: Sumber daya alam, teknologi, masyarakat, mandiri.

\begin{abstract}
Pateh and Wates Kaja hamlets are located on the hillside slopes. 180 family heads mostly live from agriculture. Unavailability of clean water in both villages, low public awareness on health and environmental hygiene, low community productivity, waterfall Jaga Satru not yet organized and published as a tourist attraction, the selling rate of salak Bali is low. Program achievements is, increasing public health with adequate clean water, cleanliness of the environment and counseling clean and healthy lifestyle. Increase public knowledge with the availability of reading books and the reading room facilities. Increased community productivity. Cost efficiency through assistance and introduction of hydram pump technology. Results of Activities is clean water system in Pateh hamlet with hydram pump method has been realized, the evaluation results show the amount of water that is compiled to the location of 43,200 liters / day. Every person needs water every day 80 liters / day then enough for 540 people or 108 families. Clean water system gravity method in Wates Kaja hamlet has been done well and water distribution more evenly. Livestock
\end{abstract}

1,2,3 Mechanical Engineering Department of Udayana University, Badung-Bali, igksukadana@unud.ac.id 
health services achievement of 30 cattle. Reforestation of 100 coconut tree daksina has been done in the waterfall environment. Publication activity Jaga Satru waterfall tour with balihoo method has been done and foreign tourist visits have increased by $100 \%$. Environmental hygiene activities featuring 3 pieces of waste bins to collect inorganic waste. Making Master Plant tour waterfall keep 100\% done.

Keywords: Natural resources, technology, community, independent.

\section{PENDAhuluan}

Kabupaten Karangasem yang merupakan salah satu dari sembilan kabupaten di Bali. Kabupaten Karangasem terletak bagian timur pulau Bali. Kabupaten Karangasem memiliki luas wilayah $859.54 \mathrm{~km}^{2}$ dengan total penduduk sebanyak 432.791 jiwa, yang terbagi dalam tujuh kecamatan antara lain: Kubu, Selat, Manggis, Rendang, bebandem, Karangasem dan Sidemen. Tingkat penduduk miskin di Kabupaten Karangasem adalah tertinggi di Bali, dengan total penduduk miskin sebanyak 17.061 jiwa dengan pendapatan rata-rata perkapita perbulan sebesar Rp.210.000,-.

Kecamatan Selat yang terdiri dari 5 Desa administrasi yaitu: Duda Timur, Duda, Desa Pering Sari, Selat, Sinduwati. Dengan luas wilayah $134,5 \mathrm{~km}^{2}$ yang dihuni oleh 69.083 jiwa yaitu laki-laki 34.669 jiwa dan perempuan 34.419 jiwa. Desa Duda Timur terdiri dari sembilan dusun antara lain: Pateh, Pesangkan, Pesangkan Anyar, Batu Gede, Dalem, Juwuk Legi, Wates Tengah, Wates Kaje dan Wates Kangin.

Dusun Pateh terdiri dari 180 kepala keluarga atau sekitar 900 jiwa, dengan penduduk tersebar di sekitar wilayah lereng munduk salak dan bukit pintu. Luas wilayahnya sekitar $1.5 \mathrm{~km}^{2}$, yang seluruhnya merupakan daerah pertanian dan perkebunan. $85 \%$ jumlah penduduknya bekerja sebagai petani, sisanya sebagai buruh, karyawan suwasta dan guru. Dusun Pateh merupakan dusun yang miskin dan tertinggal di wilayah Kabupaten Karangasem. Jadi juga merupakan daerah miskin dan tertinggal di daerah Bali. Akibat terisolirnya dusun Pateh sehingga timbul banyak permasalahan. Yang mana dalam Program ini dilakukan beberapa kegiatan untuk membantu pemecahan permasalahan desa.
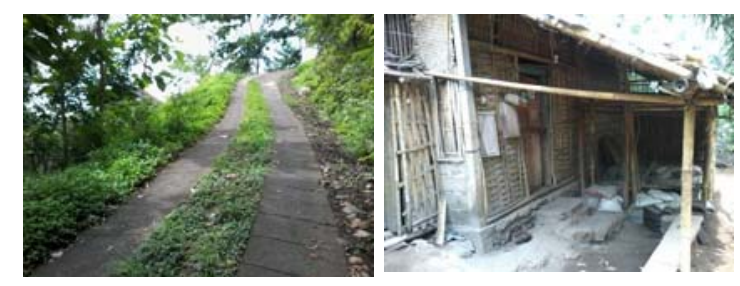

Gambar 1. Jalan menuju Dusun Pateh dan situasi rumah masyarakat (Sumber, dokumen sendiri)

Desa Duda Timur mempunyai banyak potensi yang belum sepenuhnya dikembangkan dan dimanfaatkan antra lain: Potensi dibidang pertanian dan perkebunan, hampir $90 \%$ wilayah desa Duda Timur adalah wilayah pertanian yang subur dan terbagi dalam wilayah pertanian basah hanya $5 \%$ dan $95 \%$ adalah wilayah pertanian tanah kering. 


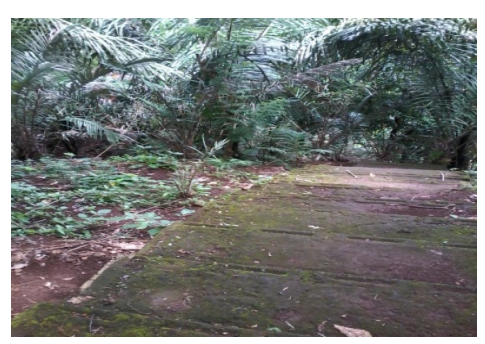

Gambar 2. Potensi pertanian

(Sumber, dokumen sendiri)

Pertanian unggulan masyarakat adalah Salak Bali dimana 90\% wilayah dusun Pateh merupakan perkebunan salak. Wilayah Duda Timur didominasi oleh wilayah perkebunan maka sumber pakan ternak tersedia sangat banyak untuk usaha pengembangan peternakan. Dilihat dari jumlah penduduk petani, $100 \%$ juga merupakan peternak dengan jumlah ternak 2-4 ekor sapi, dan 1-2 ekor babi dan rata-rata 5-10 ekor ayam kampung pada setiap keluarga. Dari $5 \%$ wilayah pertanian tanaman basah sistem perikanan air tawar memiliki potensi yang cukup besar dan sangat perlu untuk dikembangkan, seperti ikan Nila, Lele, dan ikan air tawar lainnya.

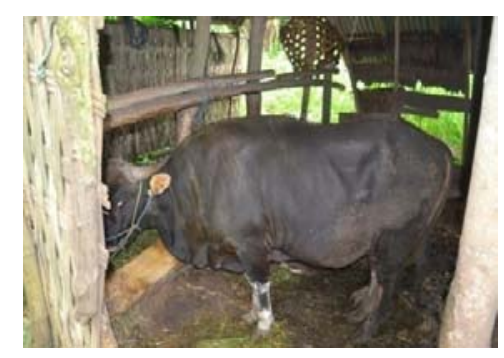

Gambar 3. Potensi peternakan (Sumber, dokumen sendiri)

Desa Duda Timur yang memiliki dan memendam banyak potensi alam seperti bambu tumbuhan perdu-perduan yang tumbuh liar di hutan yang dapat dipakai sebagai kerajinan tangan berupa anyaman yang bernilai tinggi. Desa Duda Timur juga memiliki potensi penghasil Salak Bali yang sangat besar, tetapi akibat fluktuasi harga yang sangat tinggi mengakibatkan pada musim panen justru masyarakat mengalami kerugian akibat jatuhnya harga yang terlalu rendah. Sehingga sebagian besar produk salak menjadi mubazir.

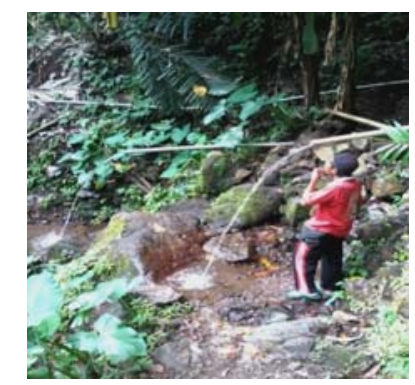

Gambar 4. Sumber air Suda Mala (Sumber, dokumen sendiri)

Desa Duda Timur memiliki banyak sumber air bersih yang dimanfaatkan untuk pertanian dan kebutuhan sehari-hari. Tetapi karena lokasi pemukiman penduduk desa Duda Timur khususnya 
Dusun Pateh berada di lereng atau punggung bukit menyebabkan pengelolaan sumber air Suda Mala untuk kebutuhan sehari-hari tidak optimal. Sehingga masyarakat yang tinggal di Dusun Pateh kesulitan untuk mendapatkan air bersih. Harus menempuh perjalanan 3 sampai 4 jam untuk mendapatkan air bersih. Sumber air Suda Mala memiliki kapasitas 5-7 liter/detik.

Potensi dibidang Energi, Air terjun Jaga Satru sebutan penduduk dusun Pateh, memiliki ketinggian 50 m, kapasitas 10 liter/detik. Potensi energy dari air terjun Jaga Satru berkisar antara 4000 watt sampai 5000 watt. Jadi potensi energy sangat besar. Energy dapat dibangkitkan dengan penerapan teknologi kincir air atau microhydro dan teknologi pompa hydram. Teknologi ini digunakan untuk menyiapan energy untuk mengangkat air ke pemukiman masyarakat.

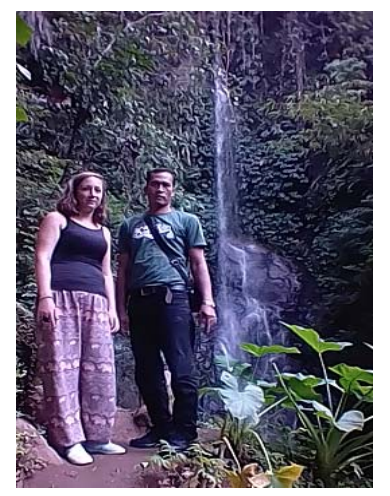

Gambar 5. Air Terjun Jaga Satru

(Sumber, dokumen sendiri)

\section{METODE PELAKSANAAN}

Memecahkan permasalah masyarakat dibidang pertanian dan perkebunan, dilaksanakan beberapa kegiatan antara lain: Kegiatan penghijauan daerah lereng dan daerah dekat sumber air dan areal jalan dengan pohon kelapa daksina. Kegiatan pendampingan pembuatan taman desa untuk mewujudkan keasrian desa. Penyelesaian masalah dibidang peternakan, untuk meningkatkan produktivitas ternak dengan melaksanakan beberapa kegiatan untuk yaitu: Meningkatkan peranan kelopok peguyuban dibidang peternakan. Penyuluhan dan pemberian vitamin dan obat cacing kepada ternak baik sapi, babi, unggas dan lain-lain.

Memecahkan permasalahan kesehatan di desa Duda Timur khususnya di dusun Pateh dilaksanakan kegiatan pembuatan sistem air bersih di Dusun Pateh dengan penerapan pompa hydram. Penyempurnaan sistem air bersih di dusun Wates Kaje dengan penerapan teknologi bak penampung/pembagi. Penyuluhan tentang pola hidup bersih dan sehat kepada anak-anak sekolah. Peningkatan kebersihan dan kesehatan lingkungan.

Penyelesaian masalah dalam bidang pendidikan dilaksanakan kegiatan memberikan pelajaran tambahan kepada anak-anak di SD Duda Timur dan penataan ruang baca di Sekolah Dasar Duda Timur. 


\section{HASIL DAN PEMBAHASAN}

\subsection{Pembuatan Sistem Air Bersih Metode Pompa Hydram}

Program air bersih dengan penerapan pompa hydram dilaksanakan beberapa kegiatan seperti: kegiatan pembersihan lahan, pembuatan bak penerjun, pembuatan pondasi pompa, pemasangan pompa, pemasangan pipa penerjun, pemasangan pipa tekan, penyetelan pompa, pengujian pompa, pembuatan bak penampung. Hasil yang dicapai pada kegiatan ini adalah terwujudnya sistem air bersih melalui penerapan teknologi pompa hydram. Dan sistem sudah bekerja dengan baik dan sesuai harapan. Jumlah kepala keluarga yang dapat dilayani sebanyak 125. Kapasitas aliran air sampai di lokasi masyarakat sebesar 0,5 liter/dt. Pompa hydram ini beroperasi selama 24 jam secara terus menerus. Dari perhitungan jumlah air yang dihasilkan sebesar 43.200 liter /hari. Kebutuhan air setiap orang setiap hari 80 liter/hari maka cukup untuk 540 orang atau 108 kepala keluarga.
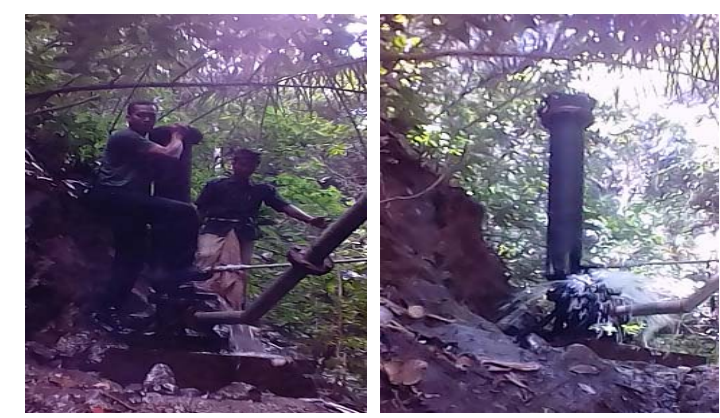

Gambar 6. Kegiatan pengerjaan sistem pompa hydram

\subsection{Pendampingan Sistem Air Bersih Metode Gravitasi di Dusun Wates Kaja}

Kegiatan pendampingan teknis dalam rangka mencari solusi untuk mengatasi kekurangan air di Banjar Wates Kaja desa Duda Timur. Adapun tahapan dari kegiatan ini antara lain: Pengadaan bak penampungan atau pembagi dan pendistribusian air ke masyarakat. Hasil dari kegiatan ini bahwa air yang mengalir di masyarakat sudah merata. Dan 250 kepala keluarga di dusun Wates Kaja sudah terlayani air bersih.
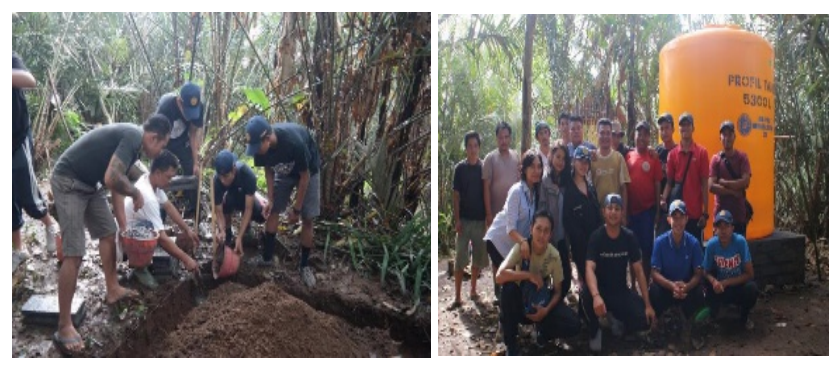

Gambar 7. Pembuatan bak pengumpul/pembagi di dusun Wates Kaje

\subsection{Kegiatan Kebersihan Lingkungan}

Kegiatan kebersihan lingkungan dilaksanakan setiap hari minggu pagi di areal kuburan desa, di areal jalan menuju air terjun Jaga Satru sepanjang $3 \mathrm{~km}$. 

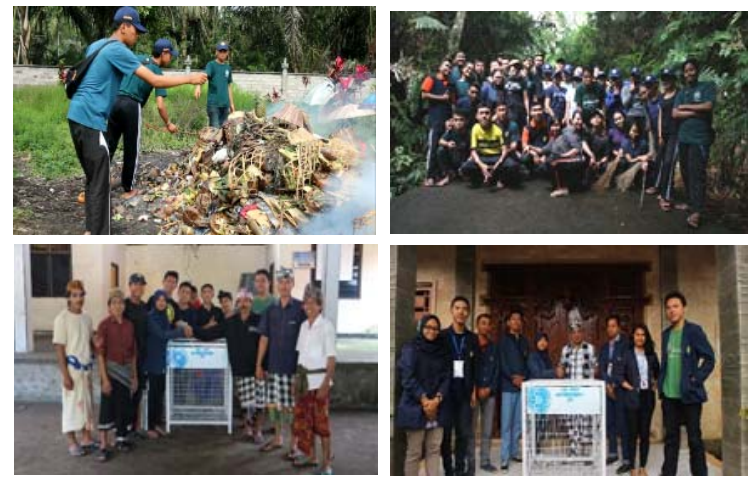

Gambar 8. Kegiatan kebersihan lingkungan dan penyerahan keranjang sampah

Kegiatan kebersihan lingkungan dilaksanakan pada setiap pagi hari dari jam 8.00 sampai 10.00 wita. Mitra yang terlibat dalam kegiatan ini semua masyarakat dusun Pateh, semua pemuda dan petugas kebersihan desa Duda Timur. Program ini membuatkan dan menyumbangkan 3 buah keranjang sampah yang digunakan hanya untuk menampung sampah plastic. Kegiatan juga diikuti dengan pemasangan poster tentang bahaya sampah plastic.

\subsection{Kegiatan Penyuluhan dan Pendampingan Pola Hidup Bersih Dan Sehat}

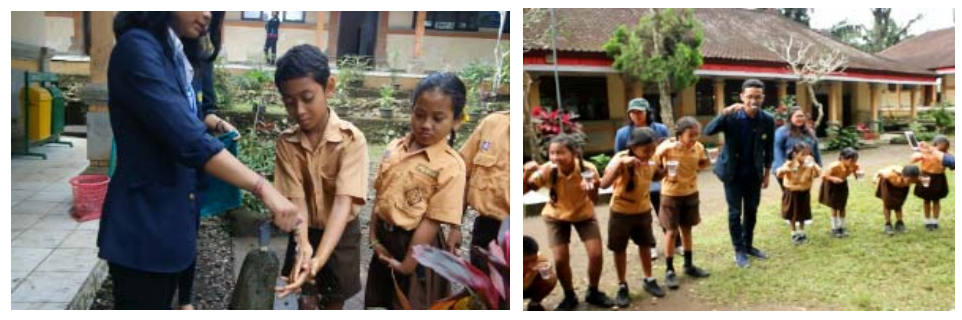

Gambar 9. Kegiatan penyuluhan dan pendampingan pola hidup dan sehat

Kegiatan pola hidup bersih dan sehat diperuntukan kepada anak Sekolah Dasar 6 Duda Timur di dusun Pateh. Sejumlah 50 orang siswa kelas 1 sampai kelas 6 di berikan penyuluhan dan pelatihan tentang bagaimana cuci tangan yang bersih, bagaimana sikat gigi yang benar, bagaimana membawa tas yang baik. Pada kegiatan ini juga dibagikan perlengkapan sikat gigi dan sabun kepada 50 siswa sekolah dasar dan anak anak lainnya yang hadir.

\subsection{Kegiatan Penyuluhan dan Pelayanan Kesehatan Ternak.}

Kegiatan pelayanan kesehatan ternak dilaksanakan dengan target layanan 60 ekor. Pelaksanaan kegiatan langsung pada kandang ternak baik kandang sapi maupun kandang babi. Pada kegiatan ini ternak diberikan vitamin, obat cacing, obat gatal kulit dan vaksin. Untuk peternak diberikan penyuluhan tentang bagaimana beternak yang sehat, seperti kandang yang sehat, membuat pakan yang sehat dengan metode silase. 

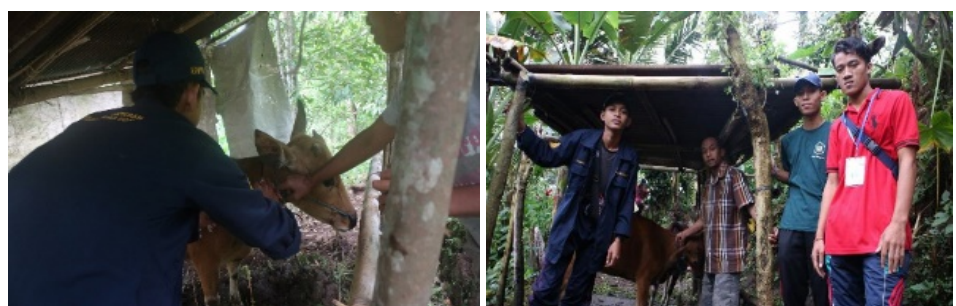

Gambar 10. Pelayanan kesehatan ternak

\subsection{Kegiatan Penghijauan di Daerah Sumber Air dan Daerah Perbukitan.}

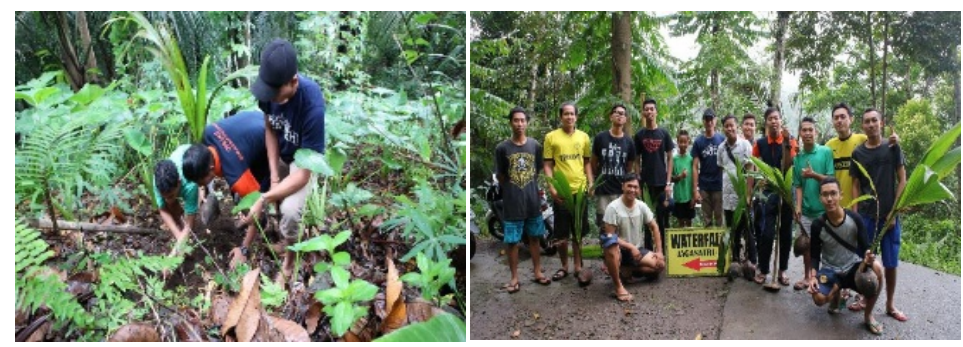

Gambar 11. Penghijauan

Kegiatan penghijauan di dusun Pateh berlokasi di wilayah lereng dan wilayah dekan sumber air. Program penghijauan ditanan 100 pohon kelapa daksina. Pohon kelapa daksina ini di tanam di pinggir jalan menuju sumber air Suda Mala dan di wilayah air terjun Jaga Satru.

\subsection{Kegiatan Pembuatan Baliho Wisata Air Terjun Jaga Satru.}
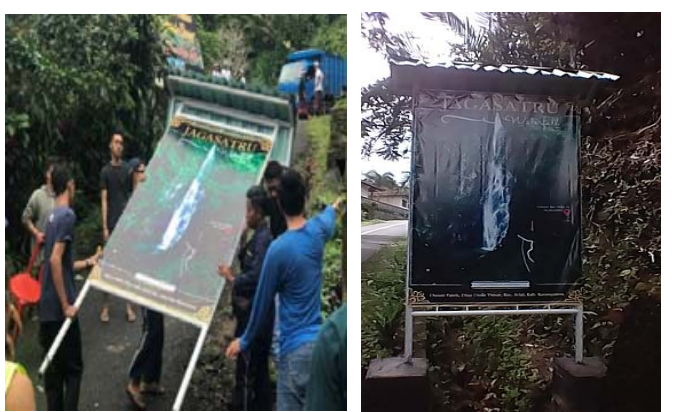

Gambar 12. Papan nama wisata air terjun Jaga Satru.

Papan nama ini berfungsi sebagai tanda pengenal dan penunjuk arah menuju objek wisata air terjun Jaga Satru dan sumber air Suda Mala. Ukuran papan nama memiliki tinggi $2 \mathrm{~m}$ dan lebar $120 \mathrm{~cm}$. Papan penunjuk ini di buat dua buah, satu di dipasang di pintu masuk desa Duda Timur dan satu lagi dipasang di jalan masuk dusun Pateh menuju air terjun. Publication activity Jaga Satru waterfall tour with balihoo method has been done and foreign tourist visits have increased by $100 \%$. 


\subsection{Pembuatan Master Plan wisata air terjun Jaga Satru}

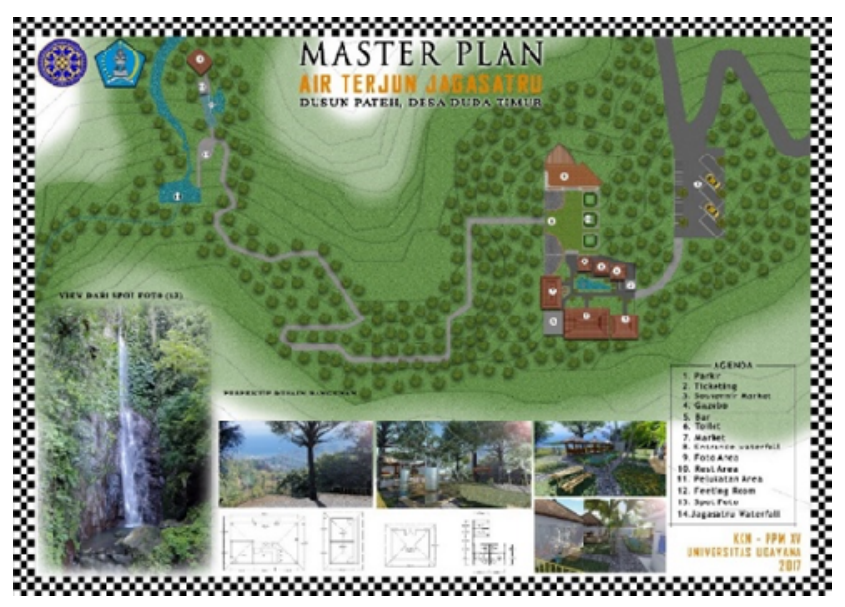

Gambar 13. Master plant wisata air terjun Jaga Satru

\section{KESIMPULAN}

Hasil kegiatan adalah sistem air bersih di dusun Pateh dengan metode hydram pump telah direalisasikan, hasil evaluasi menunjukkan jumlah air yang dikompilasi ke lokasi sebesar 43.200 liter/hari. Setiap orang membutuhkan air setiap hari 80 liter/hari maka cukup untuk 540 orang atau 108 keluarga. Metode gravitasi sistem air bersih di dusun Wates Kaja telah dilakukan dengan baik dan distribusi air lebih merata. Penyuluhan kesehatan ternak mencapai 30 ekor sapi. Reboisasi 100 pohon kelapa daksina telah dilakukan di lingkungan air terjun. Kegiatan publikasi wisata air terjun Jaga Satru dengan metode balihoo telah dilakukan dan kunjungan wisman telah meningkat sebesar $100 \%$. Kegiatan higiene lingkungan menampilkan 3 buah tempat sampah untuk mengumpulkan sampah anorganik.

Terkait dengan segala permasalahan yang ditemui dan dihadapi di desa Duda Timur khususnya dusun Pateh, maka sangat diharapkan dukungan moril untuk meningkatkan motivasi masyarakat dalam membangun desa. Selain itu diperlukan juga dukungan ilmu pengetahuan dan teknologi yang dirasa sangat penting dan sangat membantu masyarakat dalam pembangunan Desa Duda Timur, Kabupaten Karangasem.

\section{UCAPAN TERIMAKASIH}

Penulis mengucapak terima kasih kepada Kemenristekdikti Republik Indonesia dan LPPM Universitas Udayana untuk dukungannya pada kegiatan pengabdian ini melalui hibah 2017.

\section{DAFTAR PUSTAKA}

Direktorat penelitian dan pengabdian kepada masyarakat direktorat jenderal pendidikan tinggi kementerian pendidikan dan kebudayaan, 2013, "Panduan pelaksanaan penelitian dan pengabdian kepada masyarakat di perguruan tinggi”, edisi IX, Jakarta.

Direktorat penelitian dan pengabdian kepada masyarakat direktorat jenderal pendidikan tinggi kementerian pendidikan dan kebudayaan, 2013, "Panduan pelaksanaan hibah kuliah kerja nyata pembelajaran pemberdayaan masyarakat (KKN-PPM)", Jakarta. 
I.G.K. Sukadana, I.G.N.P. Tenaya, I.M. Astika

Fakultas Teknik UNUD, 2013, Buku pedoman akademik Fakultas Teknik Universitas Udayana, Bali.

Sekretariat daerah kabupaten Karangasem, 2015, "Rencana program jangka menengah daerah kabupaten Karangasem", Karangasem 